УДК 330:338.2

О.В. ПАХОЛЮК

Луцький наиіональний технічний університет

Г.О. ПУШКАР, І.С. ГАЛИК, Б.Д. СЕМАК

Львівський торговельно-економічний університет

\title{
ОЦІНКА ЕКОНОМІЧНИХ АСПЕКТІВ РОЗИТКУ НАНОНАУКИ, НАНОТЕХНОЛОГІЙ ТА РИНКУ НАНОПРОДУКЦІЇ В УКРАЇНІ В ХХІ СТОЛІТТІ
}

\author{
E. PAKHOLIUK \\ Lutsk national technical university \\ G. PUSHKAR, I. GALIK, B. SEMAK \\ Lviv trade and economic university
}

\section{ASSESSMENT OF ECONOMIC ASPECTS OF NANOSCIENCE, NANOTECHNOLOGY AND NANO PRODUCTS MARKET DEVELOPMENT IN UKRAINE IN THE XXI CENTURY}

https://doi.org/10.36910/6775-2310-5283-2021-14-22

Мета. У даній роботі нами узагальнені результати досліджень деяких вітчизняних авторів і власних досліджень, присвячених успішному розвитку нанонауки, нанотехнологій та ринку нанопродукції в Україні за останні роки, щзо тісно пов'язані із економічним стимулюванням їх розвитку зі сторони держави. У даній роботі ми для прикладу дамо аналіз деяких літературних джерел [1-15] в яких розкривається роль економічних чинників у темпах розвитку даних галузей.

На основі аналізу літературних джерел і узагальнення результатів власних досліджень метою роботи є обгрунтування доиільності державної підтримки пріоритетного розвитку перспективних нанотехнологій в Україні, які сприяють стабілізації економіки в Україні.

Методика. При проведенні досліджень використовували передбачені діючими державними стандартами методи. Виконали огляд джерел товарознавчої та економічної літератури, здійснили моніторинг і систематизацію отриманих даних.

Результати. Як свідчить зарубіжний досвід, розвиток текстильних нанотехнологій $i$ окремого сегменту ринку нанотекстилю в Украӥні сприятиме:

-необхідності державної підтримки усіх галузей нанотехнологій, товари і продукиія яких є найбільш перспективними на світовому та національному ринку нанотехнологій;

-доведена доцільність та вказані основні напрямки вдосконалення методики тестування нанопродукиії та нанотоварів як нового товару на українському ринку, а 
також вдосконалення методики оцінки новизни, безпечності та рівня якості вітчизняної нанопродукиії;

- аргументована потреба державного регулювання розвитку нанотехнологій та ринку нанопродукиії з метою руйнування щзе існуючого відставання країни в деяких галузях розвитку нанотехнологій ( а саме в галузі легкої промисловості).

Наукова новизна. Обтрунтована доцільність та сформульовані напрямки вдосконалення методики тестування нанопродукиії як нового товару на ринку України, а також вдосконалення методики оцінки новизни, рівня якості та безпечності вітчизняної нанопродукиіï.

Практична значимість. Обтрунтована потреба державного регулювання розвитку нанотехнологій і ринку нанопродукиії з метою ліквідації ще існуючого відставання країни $в$ деяких галузях розвитку нанотехнологій (особливо в галузі легкої промисловості).

Ключові слова: нанонаука, нанотехнології, нанопродукиія, економічні аспекти, пріоритетні напрямки, державна підтримка.

\section{Постановка проблеми у загальному вигляді та їі зв'язок із важливими} науковими чи практичними завданнями. Як свідчить аналіз літературних даних [1-15], успішний розвиток нанонауки, нанотехнологій та ринку нанопродукції в Україні за останні роки тісно пов'язані із економічним стимулюванням їх розвитку зі сторони держави. У даній роботі ми для прикладу дамо аналіз деяких літературних джерел [1-15] в яких розкривається роль економічних чинників у темпах розвитку даних галузей.

Як відомо розвиток окремих галузей промисловості, сільського господарства та медицини в Україні та світі, їх досягнення в останні роки в значній мірі визначаються рівнем розвитку в цих країнах нанонауки, нанотехнологій та ринку нанопродукції. Тому виникає потреба визначення пріоритетних напрямків розвитку нанонауки, нанотехнологій та ринку нанопродукції в Україні при відповідній державній підтримці найбільш перспективних із них з метою їх державної підтримки і регулювання.

Аналіз останніх досліджень, у яких започатковано вирішення проблеми. Варто відзначити, що проблемам формування та розвитку ринку нанотехнологій та нанопродукції в Україні та світі присвячена значна кількість публікацій (монографій, наукових статей, доповідей на наукових конференціях), а також видань навчального, методичного та нормативного характеру. Ми обмежимося більш детальним розглядом тільки тих публікацій, які безпосередньо пов'язані 3 формуванням розвитку нанотехнологій нанотекстилю та нанопродукції, виготовленої на його основі [1-15]. 
Цілі статті. Обгрунтування доцільності державної підтримки пріоритетного розвитку перспективних нанотехнологій в Україні, які сприяють стабілізації економіки в Україні.

Виклад основного матеріалу дослідження 3 повним обгрунтуванням отриманих наукових результатів. Автором роботи [1] узагальнено результати економічно-статистичного аналізу діяльності установ НАН України, присвячених розв'язанню проблем розвитку нанонауки та на нанотехнологій в Україні в останні роки. Наведена інформація свідчить, що основну роботу в цих галузях сьогодні виконують галузеві інститути НАН України. Саме в цих інститутах виконується переважна кількість робіт за тематикою нанотехнологій.

Автором роботи [2] розглянуто організаційно-економічні передумови здійснення розробок у сфері нанотехнологій. Наведені результати наукової діяльності установ Національної академії наук України. Виявлені найбільш перспективні напрямки розвитку нанотехнологій в Україні. Підкреслюється, що розбудова нанотехнологічної сфери в Україні може стати потужним інструментом інтеграції вітчизняного промислового комплексу до міжнародного ринку високих технологій. Автором відзначено особливості розвитку нанотехнологій в Україні, а саме:

- основними продуцентами нанотехнологій в Україні $€$ установи академічного сектору науки, які здійснюють різноманітні дослідження, які фінансуються державою;

- низька імплементація результатів нанотехнологічних досліджень, обумовлена тим, що підприємства промислового сектору для реалізації нанотехнологій вимагають більш глибоких знань і затрат;

- значна кількість розробок у галузі нанотехнологій ще не готові для реалізації на існуючому товарному ринку України;

Серед проблемних завдань необхідно відзначити такі:

- імплементацію в національну систему розвитку нанотехнологій досягнення зарубіжних країн (особливо лідерів у розвитку нанотехнологій);

- більш ефективна державна підтримка у розвитку найбільш перспективних нанотехнологій;

- подальше вдосконалення методів дослідження, властивостей, рівня якості та безпечності нанопродукції різного цільового призначення;

- суттєве розширення тематики державних наукових програм в галузі нанонауки та нанотехнологій. 
Автором роботи [3] дано аналіз директивних документів СС щодо політики європейських країн в галузі розвитку окремих нанотехнологій. Обгрунтовано доцільність використання в Україні позитивного досвіду розвитку нанотехнологій у СС. Автором обгрунтовано доцільність виконання в Україні наступної Державної цільової програми «Нанотехнології та наноматеріали на 2015-2025 роки». При цьому зусилля науковців слід сконцентрувати на таких напрямках:

- розвитку фундаментальних знань;

- активізації технологічних інновацій та їхній комерціалізації;

- забезпеченні соціально-відповідального технологічного розвитку.

Авторами роботи [4] дано оцінку результативності роботи окремих нанотехнологій у світі шляхом оцінки частки окремих видів нанопродукції. Розглянуто окремі питання розвитку системи стандартизації у сфері розвитку нанотехнологій у світі та Україні.

Авторами роботи [5] підкреслюється, що в Україні, як і в багатьох розвинутих країнах світу (особливо США, Японії, Південній Кореї, Свросоюзі) в останні роки проводяться фундаментальні дослідження нанотехнологій i нанопродукції. Разом з тим, існує нагальна потреба виявлення та обгрунтування необхідності державної підтримки окремих нанотехнологій в окремих галузях промисловості України. Автором виявлені та описані найбільш перспективні нанотехнології і наноматеріали різного цільового призначення. Обгрунтовано сфери їх найбільш раціонального використання.

Автором роботи [6] розкрито роль нанотехнологій у формуванні ринку нанопродукції в Україні та світі. Вивчено особливості розвитку технологічних i економічних аспектів нанотехнологій і ринку нанопродукції. Обгрунтована потреба державної підтримки у розвитку названих галузей в Україні.

Автор роботи [7] підкреслює, що ефективне функціонування та розвиток національної економіки, можливості іiі інтеграції у світову систему на пріоритетних засадах визначаються можливістю країни в повній мірі реалізувати інвестиційний потенціал впроваджувати виробництво конкурентоспрямованої нанопродукції. При цьому основна увага приділяється розвитку виробництва конкретної нанопродукції різного цільового призначення. Автор обгрунтовує доцільність державної підтримки саме такої нанопродукції. При цьому підкреслюється вагомість вирішення проблеми державного стимулювання розвитку перспективних нанотехнологій. Підкреслюється, що 
впровадження нанотехнологій в будь-яку галузь економіки гарантує стабільність і перспективність її розвитку.

Автором роботи [8] досліджено сучасні тенденції розвитку світового ринку нанотехнологій. Дана оцінка ринку нанотехнологій в Україні. Відзначено, що для подальшого просування України на світовому ринку необхідно розробити та впровадити комплексну програму дій, що охоплювало б інвестування та стимулювання науково-дослідної роботи у галузі розвитку найбільш перспективних нанотехнологій. Підкреслюється, що найважливішими засадами щодо розвитку вітчизняного сектору нанотехнологій має стати міжнародне науково-технологічне співробітництво. Це дозволить Україні суттєво підвищити свій статус у розвитку нанотехнологій.

Авторами роботи [9] дана характеристика основних критеріїв оцінки нанотехнологічного та інноваційного рівня промислових підприємств. Визначено фази розвитку нанотехнологій у світі. Проаналізовано співвідношення кількості нанотехнологічних компаній в окремих країнах світу. Здійснено аналіз національних програм у сфері розвитку нанотехнологій. Виявлено найуспішніші приклади реалізації окремих нанотехнологій в окремих країнах, включаючи Україну.

Автором роботи [10] проведено аналіз робіт, присвячених розвитку нанотехнологій i виробництву нанопродукції в Україні. Дано оцінку законодавчих актів України щодо вирішення цих проблем. Показано вплив розвитку нанотехнологій на процес розвитку сусідніх галузей промисловості. Обгрунтована доцільність державної підтримки розвитку пріоритетних нанотехнологій в Україні. Розглянуто проблеми подальшого розвитку ринку нанопродукції в Україні.

Авторами роботи [11] обгрунтована потреба теоретичного забезпечення формування складових механізму державної підтримки розвитку біотехнологій в Україні. Узагальнено зарубіжний досвід організації державної підтримки розвитку біотехнологій у різних галузях економіки. При цьому основна увага приділяється підвищенню якості та безпечності продукції, ऑii конкурентоспроможність, обгрунтування сфер застосування та 242рм. Підкреслюється, що механізм державної підтримки розвитку біотехнологій в Україні повинен відповідати таким вимогам: він повинен враховувати особливості технологій різних виробництв, гарантувати безпеку для споживачів продукції, гарантувати економічність та екологічність технологій виробництва і т. д. Відзначається, що теоретичне забезпечення складових 
механізму державної підтримки розвитку біотехнологій дозволяє структурувати ïx за концептуальним, нормативно-правовим та інструментальним рівнями задля повного охоплення державною підтримкою усіх етапів розвитку біотехнологій та підвищення якості управлінських рішень, що приймаються на кожному рівні.

В роботі [12] відзначається, що основними складовими інноваційної політики держави є: законодавче забезпечення; формування та підтримка розвитку інноваційної інфраструктури; прогнозування i планування інноваційного розвитку; захист інтелектуальної власності, підтримка розвитку науки та освіти; пільгове оподаткування суб'єктів господарювання, що здійснюють інноваційну діяльність; державна фінансова підтримка науководослідної діяльності та інноваційної господарської діяльності; формування сприятливого інформаційного середовища.

Авторами роботи [14] обгрунтовано економічну та екологічну доцільність формування в Україні окремого сегменту товарного ринку нанотекстилю та виготовлення на його основі різноманітної нанопродукції. При цьому, підкреслюється про необхідність поглиблення наукових досліджень у галузі розвитку нанотехнологій та ринку нанотекстилю, які виконуються у галузевих та вузівських лабораторіях сфери легкої промисловості та торгівлі України, а також створення більш досконалих методів формування та аналізу ринку нанотекстилю різного цільового призначення (одягового, медичного, військового, спеціального). Обгрунтовано та визначено вплив розвитку нанотехнологій на підвищення ефективності роботи окремих галузей вітчизняної легкої промисловості (текстильної, швейної, трикотажної). Розкрито роль та необхідність створення нормативної документації для регламентації вимог до рівня якості та безпечності нанотекстилю та методів їх оцінки. Обгрунтовано доцільність подальшого вдосконалення системи підготовки фахівців технологічного і товарознавчо-комерційного профілю для потреб легкої промисловості і торгівлі України. При цьому ці компетентності повинні бути тісно пов'язані із конкретними вимогами відповідного освітнього стандарту.

В роботі [15] авторами обгрунтовано можливості легкої промисловості України випускати сучасний асортимент нанотекстилю та наноодягу різного цільового призначення. Оцінено та обгрунтовано доцільність створення в Україні окремого сегменту ринку нанотекстилю i наноодягу в рамках загального товарного ринку, як це прийнято у багатьох економічно розвинутих 
країнах світу. Встановлено, що для тестування нанотекстилю i наноодягу як нових товарів на сучасному ринку, доцільно більш широко використовувати показники їх конкурентоспроможності, які є комплексними критеріями оцінки технічних, гігієнічних, екологічних, естетичних, економічних та інших характеристик цих товарів (особливо це стосується оцінки новизни нанотекстилю одягового, медичного та спеціального призначення). Обгрунтована доцільність поглиблення товарознавчих i маркетингових досліджень оптимальності асортименту, властивостей, а також рівня якості та безпечності нанотекстилю і наноодягу з метою інформаційного забезпечення розвитку та функціонування названого сегменту їх ринку.

Як свідчить наведена інформація, проблемам розвитку ринку нанотехнологій і нанопродукції присвячена значна кількість робіт, включаючи і дослідження асортименту та властивостей текстильної нанопродукції різного цільового призначення.

Реалізація названої мети роботи, на нашу думку, вимагає:

- вивчення та узагальнення стану розвитку нанотехнологій та ринку нанопродукції, а також використання позитивного зарубіжного досвіду їх розвитку [14];

- обгрунтування державного стимулювання тих галузей нанотехнологій в Україні, які є найбільш перспективними;

- вдосконалення методики тестування нанопродукції як нового товару на ринку України;

- застосування принципів товарознавчого та маркетингового аудиту для оцінки оптимальної структури асортименту нанопродукції, рівня якості та безпечності нанопродукції різного цільового призначення [15];

- усестороннього економічного аналізу витрат, пов'язаних із розвитком нанонауки, нанотехнологій та ринку нанопродукції в Україні.

Як свідчить зарубіжний досвід, розвиток текстильних нанотехнологій i окремого сегменту ринку нанотекстилю в Україні сприятиме:

- прискоренню темпів розвитку окремих підгалузей текстильної і легкої промисловості в Україні (особливо швейної і трикотажної);

- створенню принципово нових видів текстильної нанопродукції (інтелектуальний текстиль, медичний нанотекстиль, військовий нанотекстиль, інтер'єрний нанотекстиль, нові види спецодягу різного цільового призначення);

- розширенню асортименту та збільшенню обсягів експорту текстильної нанопродукції; 
- пошуку шляхів більш ефективного використання потенціалу вузівської науки (особливо в університетах сфери легкої промисловості та торгівлі України) для розвитку текстильних нанотехнологій i ринку текстильної нанопродукції.

Висновки та перспективи подальших досліджень. Отже, у роботі обгрунтована доцільність державної підтримки галузей нанотехнологій, продукція яких $\epsilon$ найбільш перспективною на світовому та національному ринку. Аргументована доцільність та сформульовані напрямки вдосконалення методики тестування нанопродукції як нового товару на ринку України, а також вдосконалення методики оцінки новизни, рівня якості та безпечності вітчизняної нанопродукції. Доведена потреба державного регулювання розвитку нанотехнологій i ринку нанопродукції 3 метою ліквідації ще існуючого відставання країни в деяких галузях розвитку нанотехнологій (особливо в галузі легкої промисловості).

\section{Список використаних джерел}

1. Ткачова О.А. Нанотехнології як об’єкт статистичного моніторингу: світова та вітчизняна практики. Економіка і прогнозування. 2014. № 2. С.105-124.

2. Ткачова О. А. Науково-технологічний потенціал розвитку вітчизняної сфери нанотехнологій. Економіка і прогнозування. 2015. № 2. С. 134-147.

3. Саліхова О. Б. Державна політика у сфері нанонауки та нанотехнологій в Україні 3 урахуванням орієнтирів СС . Економіка і прогнозування. 2014. № 3. С. 121-136.

4. Фесенко О. М. Проблеми та перспективи розвитку нанотехнологій в Україні та світі. Маркетинг і менеджмент інноващій. - 2017. - № 1. - С. 170-179.

5. Матюшенко I. Ю. Проблема визначення пріоритетних напрямів розвитку нанотехнологій в рамках пріоритетів розвитку науки і техніки в Україні. Проблеми економіки. 2011. № 2. С. 14-25.

6. Глухова Д. А. Розвиток нанотехнологічного бізнесу в Україні. Економіка та держава. 2010. № 12. С. 58-59.

7. Моісеєнко Ю. М. Роль нанотехнологій у забезпеченні ефективного функціонування національної економіки. Моделювання регіональної економіки. 2016. № 2(26). С. 341-349.

8. Черницька Т. В. Сучасні тенденції розвитку світового ринку нанотехнологій у глобальному середовищі. Вісник Чернігівського держсвного технічного університету. 2013. №1(64). С. 154-158.

9. Войтко С. В. Дослідження ретроспективи розвитку нанотехнологій та передумови технологічного прориву України у цій сфері. Економіка та держава. 2015. № 11. С. 18-21.

10. Кириленко Л. В. Розвиток нанотехнологій та виготовлення наноматеріалів в Україні. Журнал Логоб «Мистецтвво наукової думки». 2019. №2. С. 76-77. 
11. Бунтов I. Ю., Бєлікова Н.В. Теоретичне забезпечення формування складових механізму державної підтримки розвитку біотехнологій в Україні. Бізнес Інформ. 2018. №1. C. 93-98.

12. Казаков В. В. Организационно-финансовый механизм формирования и реализации инновационной политики экономических систем. Вестник Томского государственного университета. 2012. №363. С. 157-164.

13. Тарасюк М.В., Малярчук О.В. Сучасний стан реалізації інноваційної політики України та їі фінансове забезпечення. Економіка та держава. 2017. №1. С.19-24.

14. Пушкар Г.О., Галик І.С., Семак Б.Д. Обгрунтування доцільності формування в Україні окремого ринку нанотекстилю та вдосконалення методів оцінки ефективності його функціонування. Вісник Львівського торговельно-економічного університету. 2020. Вип.24. Технічні науки. С. 50-57.

15. Пахолюк О.В., Пушкар Г.О., Галик І.С., Семак Б.Д.Товарознавчі та маркетингові аспекти формування вітчизняного ринку нанотекстилю і одягу. Вісник Хмельницького національного університету. 2019. № 6. С. 53-57.

\section{Reference}

1. Tkachova O.A. (2014). Nanotekhnolohiyi yak ob'yekt statystychnoho monitorynhu: svitova ta vitchyznyana praktyky [Nanotechnologies as an object of statistical monitoring: world and domestic practice] Ekonomika i prohnozuvannya [Economics and forecasting]. 2014. № 2. S.105124.

2. Tkachova O.A. (2015). Naukovo-tekhnolohichnyy potentsial rozvytku vitchyznyanoyi sfery nanotekhnolohiy [Scientific and technological potential for the development of the domestic sphere of nanotechnology] Ekonomika i prohnozuvannya [Economics and Forecasting]. 2015. № 2. S. 134-147.

3. Salikhova O.B. (2014). Derzhavna polityka u sferi nanonauky ta nanotekhnolohiy v Ukrayini $\mathrm{z}$ urakhuvannyam oriyentyriv YES [State policy in the field of nanoscience and nanotechnology in Ukraine, taking into account the guidelines of the EU]. Ekonomika $i$ prohnozuvannya [Economics and Forecasting]. 2014. № 3. S. 121-136.

4. Fesenko O.M. (2017). Kovalchuk S.V., Nyshchyk R.A. Problemy ta perspektyvy rozvytku nanotekhnolohiy $\mathrm{v}$ Ukrayini ta sviti [Problems and prospects of nanotechnology development in Ukraine and the world. Marketynh i menedzhment innovatsiy [Marketing and innovation management]. 2017. № 1. S. 170-179.

5. Matyushenko I.Y. (2011). Problema vyznachennya priorytetnykh napryamiv rozvytku nanotekhnolohiy $\mathrm{v}$ ramkakh priorytetiv rozvytku nauky i tekhniky $\mathrm{v}$ Ukrayini [The problem of determining the priority areas of nanotechnology development within the priorities of science and technology development in Ukraine]. Problemy ekonomiky [Problems of economy]. 2011. № 2. S. 14-25.

6. Glukhova D.A. (2010). Rozvytok nanotekhnolohichnoho biznesu v Ukrayini [Development of nanotechnological business in Ukraine]. Ekonomika ta derzhava [Economy and State]. 2010. № 12. S. 58-59.

7. Moiseenko Yu.M. (2016). Rol' nanotekhnolohiy u zabezpechenni efektyvnoho funktsionuvannya natsional'noyi ekonomiky [The role of nanotechnologies in ensuring the effective functioning of the national economy]. Modelyuvannya rehional'noyi ekonomiky [Modeling of the regional economy]. № 2 (26). 2016. S. 341-349. 
8. Chernytska T.V. (2013). Suchasni tendentsiyi rozvytku svitovoho rynku nanotekhnolohiy u hlobal'nomu seredovyshchi [Modern tendencies of development of the world market of nanotechnologies in the global environment]. Visnyk Chernihivs'koho derzhavnoho tekhnichnoho universytetu [Visnyk of Chernihiv State Technical University]. 2013. №1 (64). S. 154-158.

9. Voitko S.V., Melnyk Ya.D. (2015). Doslidzhennya retrospektyvy rozvytku nanotekhnolohiy ta peredumovy tekhnolohichnoho proryvu Ukrayiny u tsiy sferi [Research of retrospective development of nanotechnologies and preconditions of technological breakthrough of Ukraine in this sphere]. Ekonomika ta derzhava [Economy and State]. 2015. № 11. S. 18-21.

10. Kyrylenko L.V. (2019). Rozvytok nanotekhnolohiy ta vyhotovlennya nanomaterialiv v Ukrayini [Development of nanotechnologies and manufacturing of nanomaterials in Ukraine]. Zhurnal Lohos «Mystetstvo naukovoyi dumky» [Journal Logo "Art of scientific thought"]. 2019. №2. S. 76-77.

11. Buntov I.Y., Belikova N.V. (2018). Teoretychne zabezpechennya formuvannya skladovykh mekhanizmu derzhavnoyi pidtrymky rozvytku biotekhnolohiy v Ukrayini [Theoretical support for the formation of the components of the mechanism of state support for the development of biotechnology in Ukraine]. Biznes Inform [Business Inform]. 2018. № 1. S. 93-98.

12. Kazakov V.V. (2012). Organizatsionno-finansovyy mekhanizm formirovaniya i realizatsii innovatsionnoy politiki ekonomicheskikh system [Organizational and financial mechanism of formation and implementation of innovation policy of economic systems]. Vestnik Tomskogo gosudarstvennogo universiteta [Bulletin of the Tomsk State University]. 2012. №363. S. 157-164.

13. Tarasyuk M.V., Malyarchuk O.V. (2017) Suchasnyy stan realizatsiyi innovatsiynoyi polityky Ukrayiny ta yiyi finansove zabezpechennya [The current state of implementation of innovation policy of Ukraine and its financial support]. Ekonomika ta derzhava [Economy and State]. 2017. №1. S.19-24.

14. Pushkar G.O., I.S. Halyk, B.D. Semak (2020). Obgruntuvannya dotsil'nosti formuvannya v Ukrayini okremoho rynku nanotekstylyu ta vdoskonalennya metodiv otsinky efektyvnosti yoho funktsionuvannya [Substantiation of expediency of formation in Ukraine of a separate market of nanotextiles and improvement of methods of estimation of efficiency of its functioning]. Visnyk L'vivs'koho torhovel'no-ekonomichnoho universytetu [Visnyk of Lviv State University of Trade and Economics]. 2020. Issue 24. Technical sciences. S. 50-57.

15. Pakholyuk O.V., G.O. Pushkar, I.S. Halyk, B.D. Semak (2019). Tovaroznavchi ta marketynhovi aspekty formuvannya vitchyznyanoho rynku nanotekstylyu i odyahu [Commodity and marketing aspects of the formation of the domestic market of nanotextiles and clothing]. Visnyk Khmel'nyts'koho natsional'noho universytetu [Bulletin of Khmelnytsky National University]. 2019. № 6. S. 53-57.

The purpose. In this paper, we summarize the results of research by some domestic authors and our own research on the successful development of nanoscience, nanotechnology and the market of nanoproducts in Ukraine in recent years, which are closely related to economic stimulation of their development by the state. In this paper, we give an example of the analysis of some literature sources [1-15] which reveals the role of economic factors in the pace of development of these industries.

Based on the analysis of literature sources and generalization of the results of own research, the purpose of the work is to substantiate the feasibility of state support for the priority development of promising nanotechnologies in Ukraine, which contribute to the stabilization of the economy in Ukraine. 
Methodology. During the research, the methods provided by the current state standards were used. We reviewed the sources of commodity and economic literature, monitored and systematized the data obtained.

Results. According to foreign experience, the development of textile nanotechnologies and a separate segment of the nanotextile market in Ukraine will contribute to:

- the need for state support of all branches of nanotechnology, whose goods and products are the most promising in the global and national nanotechnology market;

- the expediency is proved and the main directions of improvement of a technique of testing of nanoproducts and nanowoods as the new goods in the Ukrainian market, and also perfection of a technique of an estimation of novelty, safety and level of quality of domestic nanoproducts are specified;

- substantiated the need for state regulation of nanotechnology development and the nanoproduct market in order to destroy the country's still lagging behind in some areas of nanotechnology development (namely in the field of light industry).

Scientific novelty. The expediency and formulated directions of improvement of the method of testing nanoproducts as a new product on the market of Ukraine, as well as the improvement of the methods of assessment of novelty, level of quality and safety of domestic nanoproducts are substantiated.

Practical significance. The need for state regulation of nanotechnology development and the nanoproduct market is substantiated in order to eliminate the country's still lag in some areas of nanotechnology development (especially in the field of light industry).

Keywords: nanoscience, nanotechnologies, nanoproducts, economic aspects, priority directions, state support.

Стаття рекомендовано до публікаиії доктором технічних наук, професором Луиького НТУ Байдаковою Л.І. Дата надходження в редакиію 14.01.2021 p. 